University of Warwick institutional repository: http://go.warwick.ac.uk/wrap This paper is made available online in accordance with publisher policies. Please scroll down to view the document itself. Please refer to the repository record for this item and our policy information available from the repository home page for further information.

To see the final version of this paper please visit the publisher's website. Access to the published version may require a subscription.

Author(s): Peter J. Burnell

Article Title: International democracy promotion: a role for public goods theory?

Year of publication: 2008

Link to published version: http;//dx.doi.org/

10.1080/13569770801913249

Publisher statement: None 


\section{International democracy promotion: a role for public goods theory?}

Peter Burnell, Dept. of Politics and International Studies, University of Warwick, England*

The state of international democracy promotion is in flux. After more than fifteen years of increasing activity and with more organisations and resources devoted to promoting democracy than ever before, a mood of uncertainty surrounds democracy support's current performance and future prospects. The last decade has also seen the emergence of a new literature on global public goods theory, offering fresh analytical perspectives on pressing issues in international affairs like peace, security, development, and environmental sustainability. The future of democracy promotion will be determined chiefly by the realities of the political market place, in societies on both sides of the relationship. But could recent theorising about the market for global public goods offer some analytical support for making sense of its current condition and, by identifying the democratic peace as a global public good strengthen the case for greater international cooperation in promoting democracy as means to achieve that end?

Key words: democracy promotion; global public goods

\section{Introduction}

This article begins by noting the malaise that currently hangs over the international democracy promotion industry and then draws attention to recent literature that seeks

\footnotetext{
* The author thanks the referees of Contemporary Politics for constructive comments on an earlier version.
} 
to identify global public goods. Its main purpose is to show whether that literature has the potential to offer insights into the current condition and future prospects of international democracy promotion, by throwing features of the 'market' for democracy promotion on both the supply and demand side into sharper relief. Like recent applications of global public goods theory to international problems, this inquiry should be viewed more as a tentative exploration than a set of definitive answers to some inherently problematic big analytical and real world political questions. The idea of global political goods has recently gained in international recognition because advocates believe it offers a powerful framework for developing arguments in favour of more international cooperation and greater international provision in response to major global ills. It does not command universal acceptance. But can the framework be extended to lend support to international democracy promotion especially given the connections that many of its supporters make between democracy and democracy promotion with the desirability of progress towards greater international peace? Indeed, could international democracy promotion itself be a kind of international public good, and if so, how should the market-place for it be described? Before addressing these questions it will be useful to briefly summarise some recent trends in democracy promotion.

\section{Rising Supply, Falling Confidence}

Since the late 1980s there has been a steady and politically significant increase in activities that are variously labelled international democracy promotion, democracy support, and democracy assistance, together with a growing number of organisations in many countries and expanding budgets designed to support these activities. Democracy assistance usually refers to non-coercive and concessionary political 
assistance projects or programmes, sometimes financial or material but more often taking the form of technical support and transfers of knowledge about democracy and how to establish and consolidate democracy. In contrast democracy promotion can mean a much wider range of approaches or strategies, using such instruments as diplomatic pressure, the linking of relevant political conditionalities to financial, commercial, or political agreements. Support to national economic and social development, which the democratization literature views as beneficial if not indispensable for sustainable democracy in developing countries, offer a further variant. The differences between approaches are elaborated and discussed further elsewhere (Burnell 2005 and 2008). For the practitioners of democracy promotion just as for much of the academic literature on democratization, democracy is understood in terms of western-style liberal democracy, akin to what Robert Dahl famously called polyarchy. It is more than just elections; it includes extensive political and civil liberties; and it differs from the deliberative notions that feature in some contemporary theorising on democracy's meaning, while being far removed from the more radical participatory grass-roots models that much emancipatory theory recommends. This article dwells mainly on the subject of democracy assistance and takes the polyarchical understanding of democracy as a given, but that does not mean they should not be subjected to close critical examination.

The democracy promotion industry is multinational and its size at an all-time high. Current spending ranges somewhere between US\$5 and \$10 billion annually; definitional problems and data limitations prevent more precise and universally acceptable estimates. Some of the longest established actors are Germany’s Stiftungen (political foundations), for whom democracy support abroad complements extensive 
civic education work at home. More countries than ever have their own publicly funded institutes, foundations, government departments or sub-departments either dedicated to or involved in democracy promotion activities. Inter-governmental organisations too are now very actively involved, ranging from the Commonwealth to the Organisation for Security and Cooperation in Europe. One of the largest is the United Nations Development Programme, which claims to support democratic governance in over 130 countries. Also, 2005 saw the launch of a new United Nations Democracy Fund. Intergovernmental organisations at the regional level for example the Organization of American States have committed themselves to maintaining democratic rule in the member states. And the European Union (EU) and its members broadly match the commitment to assisting democratic progress in other countries that the United States government provides through its United Sates Agency for International Development (USAID) and the publicly-funded National Endowment for Democracy (NED, founded in 1983) together with its affiliates the National Democratic Institute and International Republican Institute. The activities of these and other organisations are increasingly well documented - if not yet fully understood - in a now substantial literature on democracy promotion. Indeed, growth in academic and other independent commentary has been both a consequence and a contributory factor in the enhanced prominence achieved by international democracy promotion, especially in the established democracies. The International Institute for Democracy and Electoral Assistance, in Stockholm, has played a part in this. As a research institute and knowledge bank it specialises in offering that most classic of public goods, relevant knowledge, on an impartial, global and non-profit basis. And yet not only have observers tended to highlight shortcomings and other troubling features of 
democracy promotion, which was bound to happen, but the current mood in and around the industry itself appears to be at an all-time low.

While this combination of rising supply and falling confidence is not necessarily paradoxical the reasons have been much speculated on: only the most important will be briefly mentioned here. Pride of place is usually given to the confusion of democracy assistance with what in the light of the US response to 9/11 has come to be known as 'regime change' - the forcible removal of governments that are accused of being despotic and unfriendly to human rights, and which may enable democratic rule to be put in its place, for foreign policy reasons that are very different. The military interventions to overthrow the Taliban in Afghanistan (2001) and Saddam Hussein in Iraq (2003) are the paradigm cases. Arguably the objective and the means used both flouted international law. These interventions, compounded further by the failure to usher in stable democratic government have cast a long shadow. Although not constituting a serious logical challenge to the claims to legitimacy of democracy assistance, they have made it possible for democracy promotion tout court to attract condemnation by association. For rulers with no or very questionable liberal democratic credentials, the Iraq war and subsequent events have probably made it easier to mobilise nationalist resentment against external efforts to bring democracy. In addition, the growing assertiveness of President Putin's international stance (see Ambrosio 2007, for how this has been influenced by Putin’s domestic political agenda), backed by Russia's dramatically improved financial fortunes courtesy of the greatly increased international price of oil, and the riches now accruing to some commodity exporting developing world governments as a result of rising demand from the booming economies of China and India, have all served to reduce the 
leverage that western governments could exert on behalf of democracy promotion. In several important countries then the 'backlash against democracy promotion' is nothing short of a 'pushback against democracy' itself. Perhaps even more portentous, the 15 June 2006 Declaration of the Shanghai Cooperation Organisation, which includes China, Russia and several Central Asian states, appeared to invoke the short step from upholding authoritarian rule at home to the collective provision of counterpromotion measures and an increase in mutual political support to one another abroad

Beginning in 2006 terms like 'rollback', backlash' and 'pushback' have come to be bandied around for depicting a climate for democratisation and more specifically for welcoming democracy support that has turned hostile in many places (see for example Carothers 2006a; Carothers 2006b; Gershman and Allen 2006; Puddington 2007). More specifically for the EU, the easy 'victories' have now been won. The political conditionalities that the EU attached to eligibility for accession, embodied in the 1993 Copenhagen agreement, have done their work in helping former communist states in Central and Eastern Europe build on their democratic transitions that were already underway. For them, democratisation was an obvious choice if they were to leave the Soviet/Russian embrace. Now, in the 'European neighbourhood' and more distant countries, where the reform incentive from joining the EU is not on offer, EU hopes of inducing substantial democratic progress look far less realistic, especially in countries like Belarus where no strong domestic impetus for democratic transition exists. Even so, future levels of support for democracy promotion from Europe (where in 2007 a new European Instrument for Democracy and Human Rights was endowed with 1.1 billion Euros over the next seven years) and some smaller actors like Australia's Centre for Democratic Institutions look more secure than does the 
commitment of the United States. In the US the return of a vigorous security-driven realism shaping the Bush administration’s foreign policy, a recognition that elections elsewhere can produce outcomes unfavourable to US interests (as in President Chavez’ Venezuela and Palestine’s Hamas in 2006), plus speculation that the next administration will want to distance itself from President Bush’s high-profile verbal embrace of freedom and democracy objectives, all sustain a belief that the political commitment to promoting democracy abroad could now have passed its peak. The lack of 'follow-through' in US democracy promotion as the Bush administration has reverted more wholeheartedly to former policies of supporting states like Saudi Arabia and Egypt (in July 2007 both negotiated very large arms deals with the US) considered important allies in the war on terror and important to US security interests - is another large part of the despondency among US supporters of democracy promotion

In the early 1990s democracy promotion was supposed to help rescue international development aid from what at the time was seen to be a growth in 'aid fatigue'. Following a UN-sponsored international conference on financing development, in Monterey, Mexico, 2002, development aid spending has recovered and development cooperation with the poorest countries has gained a new lease of life. Now it is democracy support that appears to be in trouble. At times like this, when the sentiments expressed by experts such as Thomas Carothers and prominent academics like Larry Diamond (2007), supplemented by the writer’s own observations in regular encounters with democracy assistance advisers and practitioners, range from caution to despair, can global public goods theory come to the rescue - in the sense of offering a new, more positive lens through which to 
examine international democracy promotion, both the supply and demand? Or does it point to deeper limitations than just the policy mistakes that have been made in regard to regime change especially and the inevitable obsolescence of the enlarging EU's apparent record of success?

\section{Public Goods and Global Public Goods}

Public goods analysis has been applied to global problems for some time, but in contrast to globalization and as Kaul, Grunberg and Stern (1999b: xxii) remark, discussion of what global public goods really are and the candidates has been sparse. That began to change in the late 1990s and the beginnings of a new literature (drawn on extensively here) questioning the adequacy of traditional concepts and theories of public goods for understanding current international realities (for example Kaul, Grunberg and Stern 1999a; Kaul, Conceição, Le Goulven and Mendoza 2003a). International financial stability, a multilateral trade regime, reducing the excessive disease burden, preventing deadly conflict, climate stability, and a global communications network are typical if disparate examples of what are now being cited as global public goods, namely goods whose benefits are almost universal in terms of countries, people, and generations.

Classically, public goods are goods that when supplied are necessarily supplied to everybody. They are non-rivalrous in consumption (consumption by one party leads to no subtraction from any other party's consumption) and the benefits are non-exclusionary (non-payers are not denied access): this latter makes free riding possible. However, there is no logical requirement that all derive equal benefit or utility. And in practice for many people there may even be barriers to access. In 
reality, pure public goods are probably rare; but there are impure public goods which possess public good attributes, while also being partly private. It is not unusual for the term public good to be used to encompass the pure and impure varieties.

To qualify as a public good does not require that the good already is or should be supplied by a public body. But the closer a good is to becoming a pure public good, then the more likely that the market - in the sense of market-based transactions carried out for profit by non-state actors - will undersupply it, or not supply it at all. For this reason public goods are often dubbed a case of market failure. Lighthouses offer an illustration: although some have been built and operated by voluntary subscription, and some are financed by the levy of local harbour dues (which can be avoided by ships that merely pass in the night), fully adequate provision is often left to the tax system and publicly-funded (if not also publicly-delivered) supply.

A public good's peculiar status and the special arrangements needed to ensure provision have long featured in accounts of the roles of state and market in the domestic political economy. More recently, debates in international political economy have started to develop the idea of global public goods, identifying comparable problems of global underprovision, even though some of official development assistance can be said to address specific global public goods needs as well as the purely national or local needs of developing country recipients. Indeed even some country-specific aid programmes may take on an international public goods character once all the positive externalities are taken into account. To illustrate, Kaul, Grunberg and Stern (1999c: 12) say that a poverty alleviation programme in Africa could be a global public good if it contributes to conflict prevention and international peace. 
What is more, they argue that when attention is switched to the international arena there are grounds for being less rigid in determining what qualifies as a public good even if not for relaxing the classical definition (the literature here is not entirely clear on the difference). In fact some of the writers go as far as to say that decisions on what are global public goods are a matter of policy choice and to that extent the goods are a social construct (for example Kaul and Mendoza 2003: 104): 'In any event, the defining characteristic of many public goods are not inherent and are often socially endogenous' (Kaul and Mendoza 2003: 86). For this reason we should accept that the public goods status of some goods may be variable and subject to change, even if the strict definition of a pure public good remains constant.

\section{Global Public Goods, Peace and Democracy}

Peace and security, law and order and development are pure public goods on any conventional definition. International peace and global security are among those goods now being said to be quintessential global public goods, in substance and form (for example Mendez 1999: 404). And peace and security are two rationales that have featured prominently in accounts of the policy drivers for democracy promotion. Jünemann and Knodt (2007: 360-1) for instance call the democratic peace thesis a 'leitmotif' of EU foreign relations and a primary explanation of its democracy support activities in the neighbourhood. US President Clinton frequently referred to a democratic peace; and both the EU and (even more so) President George W. Bush have argued that democracy is an antidote to terrorism and presented democracy support as useful to the war on terror although more scholarly inspection is less supportive of such claims (see for example Dalacoura 2006). Moreover peace and security underpin other global public goods like sustainable development and poverty 
reduction. According to Mendez (1999: 388) 'Welfare economists, in fact, may deem peace even more fundamental than a public good. They may consider it an enabling institution of the market mechanism and an essential element of the first fundamental theorem of welfare economics' (presumably without losing its public good status).

That international peace is a pure global public good looks beyond contestation. More debatable perhaps is the inclusion (by Kaul, Conceição, Le Goulven and Mendoza 2003b: 44) of the institutional infrastructure to foster universal human rights, transparency and accountable governance in the international community's vision of the 'global public domain'. Yet in so far as most governments either claim to be democratic or to be moving towards it, democracy or at minimum some of its leading features could be considered a national public good, even though it is often more of an aspirational good and may be little more than a rhetorical good in some places. The idea of a democratic peace in international affairs looks more like a global public good. It has the properties of non-excludability and non-rivalry. The idea that democracies do not go to war with other democracies is of course one of the best known and most durable claims in international relations theory, albeit not one that has gone unchallenged in the voluminous commentary. And while a democratic peace may be considered a final global public good the same credentials may well not apply to all the purported benefits of democratisation let alone international democracy support, even though support for democratisation can be argued to be one pathway to realising peace, both within conflict-ridden societies and in the relations between societies, that is, for a domestic democratic peace and peace among democracies. 
While one society's enjoyment of liberal democracy of course does not reduce another's access to that good, the international resources that are consumed through supporting its democratic development will necessarily be denied to others: there is an opportunity cost. The democracy assistance will be a private good to the country in question, even when publicly funded and provided by public agents. And yet the 'neighbourhood effect', confirmed by findings suggesting that the chances of a country democratising tend to increase when it is situated next to democratic neighbours, indicates there can be positive spill-over effects across borders even from such 'private' goods (see for example Brinks and Coppedge 2006). To the extent that this obtains, even democracy promotion, then, might be said to at least share some of the properties of an impure regional public good. It may also be worth noting that over 100 countries belong to the Community of Democracies, an intergovernmental organization of democracies and democratizing countries at the United Nations ostensibly committed to strengthening and deepening democratic norms and practices worldwide, which offers some support to McFaul's (2004-05) claim that democracy promotion has become a 'world value'-opponents and not its supporters have the onus of justifying their position - even if not yet an accepted global public good

A further boost to the clues to the identity of global public goods especially in the context of policy-oriented debate came with the publication of the report Meeting Global Challenges: International Cooperation in the National Interest, of the International Task Force on Global Public Goods (2006). What began as an initiative of the French and Swedish governments presented its report first to the Annual Meeting of the International Monetary Fund and World Bank group in 2006. While acknowledging there can be important provision of global public goods at the national 
level it argued strongly for increased international cooperation so as to ensure an adequate supply. And although international democracy promotion is nowhere mentioned, ends like peace and security as well as development, which democracy promotion is supposed to help, are very prominent.

The Report advances the view that global public goods are 'issues that are broadly conceived as important to the international community, that for the most part cannot or will not be adequately addressed by individual countries acting alone and that are defined through a broad international consensus or a legitimate process of decision-making' (International Task Force 2006: viii). Of particular significance is that as well applying the term global public goods to highly valued end conditions like peace, the Report follows Kaul, Grunberg and Stern’s (1999c: 13) lead by including 'intermediate' public goods, that is to say the institutional or instrumental mechanisms by which the final outcomes can be secured. Accordingly many public goods 'are not abstract concepts; they are instruments to address real-world problems’ (International Task Force 2006: ix). So, just as lighthouses are often cited as examples of a public good when the desired outcome (the good) is safe passage, so an international financial regulation or regulatory regime that secures international financial stability too becomes a global public good. The same reasoning could be extended to other arenas. Thus Hamburg and Holl (1999: 377) imply that when democracy support becomes essential to establishing a ‘culture of prevention' of deadly conflict (a 'key public good') it too becomes an important public good.

The Report also confirms that while a global public good is a good whose benefits could in principle be enjoyed by the governments and people of all states, 
there are also international public goods, which simply benefit more than one country or group. Crucially it says that for any particular good to qualify as a global public good does not require universal agreement. Once again, the claim is made that a particular good's status is contingent on policy choice. 'A critical reality of global public goods is that they are contested; states have different interests, values and preferences, even where they share long-term goals' (International Task Force 2006: 86). Governments of every political persuasion have been known to sacrifice public goods for short term interest from time to time; some even question the longer term 'goodness' of a purported good, such as an open trading system, and even more so the international institutional framework for achieving that end. But this does not remove the applicability of the concept. And thus it seems that for democratic peace or perhaps democracy support to possess global, or more modestly, international public good properties, the absence of serious opposition in the real world is not a requirement.

The Report makes the conventional observation that the 'very nature of global public goods means that demand will tend to outweigh supply' (International Task Force 2006: viii). This has always been true of democratic peace in international affairs, which of course explains how international democracy promotion has come to be offered as a panacea. In fact in contemporary debate there are examples of democratisation (and hence by implication democracy support) being considered as a solution, whole or in part, to every one of the six main clusters of 'global security' threat that the Report lists from UN sources: war between states; internal conflict; terrorism; organised crime; the use and spread of weapons of mass destruction; and poverty, infectious disease and severe environmental degradation. In all cases the 
right response to market failure is said to include at minimum greater intergovernmental cooperation. If this holds true of a democratic peace then there must be implications for international democracy promotion too. But what does the market for democracy promotion look like, assuming a market exists: are the demand and the supply easy to characterise?

\section{Market-place for International Democracy Promotion}

A market is an institution in which exchanges take place in a more or less patterned way (Hodgson 2001: 982). There is a demand and a supply. The existence of markets (or a market place), where public bodies may be among the parties to the deals, can be distinguished from the more specialised conception of market exchange associated with private goods and 'free market' forces. Public goods theory tells us that non-state actors in the market for private goods will under-provide public goods. In fact in democracy assistance all the main suppliers obtain the bulk of their resources from public funds; and governmental and intergovernmental multilateral agencies are prominent providers. But what do we really know about the demand and the supply?

\section{Demand-side}

Amartya Sen (1999) famously said that by the end of the twentieth century democracy had become a universal value - its status as a universally relevant system now accepted. That oppressed peoples in many parts of the world have expressed demands for more freedom and more democracy, sometimes at great personal risk is undeniable. It is also true that all the demands are still far from being fulfilled: the good of democracy is underused; moreover in some countries the levels of democracy and its quality are being eroded. But not all democratic aspirations equate to what the 
international democracy promoters understand by democracy - a point partly conceded in their customary declaration that it is not their intention to export a particular model of democracy let along try to impose liberal democracy per se, which would be an oxymoron. The mantra 'democratic politics cannot be transplanted to or imposed on a country from outside...The demand for democratic politics must come from within (Department for International Development- DfID 2007: 3) is quite often although not always accompanied by remarks that suggest democracy’s character too must reflect local circumstances.

Worldwide support for the idea of democracy is born out by the kind of evidence collected in democracy barometers or attitude surveys that are now routinely administered across regions such as Africa, post-communist Europe, Latin America and elsewhere. DfID (2007: 20) claims that 80 per cent of respondents in a poll of 50,000 people across 65 countries in 2005 said democracy is the best system of government. However there are at least three grounds for caution about such claims, even while bearing in mind that statements purporting to identify what counts as a (global) public good seem almost bound to be open to contestation. First, in some non-democracies the ruling authorities do not allow opinions on this matter to be expressed freely even in the form of attitude surveys let alone the more conventional political and social channels associated with a relatively free society. Where the free expression of demand is suppressed, estimates of inferred demand may be the best we can hope for. Second, the most recent democracy barometers (see 'The Democracy Barometers (Part I)(2007) reveal significant and growing evidence that support for democracy is eroding or becoming more ambivalent in a number of places - so much so that Carothers (2006b) went so far as to say US democracy promoters 'can no 
longer assume a majority of citizens in countries where they work believe that democracy is necessarily the best political system' (which of course does not say they actually oppose democracy). In Russia alone the data appears to indicate that more than 50 million people are comfortable with the idea of being ruled by a dictator. The reasons behind the opinion trends are usually thought to include an unfavourable experience of democracy, the persistence of pressing socio-economic problems in particular - although the bearing this has on people's political views is not uniform and may not be clear-cut. The inability of such political institutions as the political parties and the politicians themselves to command popular respect has also played a part, although this may offer less ground for being disillusioned with the idea of democracy than it provides evidence of democratic shortfalls in the 'new democracies'. Third, perhaps in no country where liberal democracy has not already been tried successfully should evidence of either strong or weak support for the idea of democracy be assigned total credence, and of course even strong support can be translated only imperfectly into claims about demands for the introduction of democracy - a process of change that people might judge hazardous and likely to be accompanied by grave side-effects, for example political instability and potential for inter-communal conflict.

Anyway, evidence from the barometers reminds us not to dismiss lightly all the arguments against democratic reform made by ruling elites in countries that are not liberal democracies. Even the literature on democratisation harbours some genuine reservations about democracy’s appropriateness to all cases, while not actually calling it a demerit good. The reservations are usually couched in the form of doubts about whether western style liberal democracy suits every society especially at 
this moment in its history. Thus in some Islamic societies there are very real difficulties in reconciling some parts of the religious credo with major tenets of liberal democracy, most notably in regard to the idea that the people are sovereign and that men and women should share power equally. Another argument, well rehearsed in the past in the context of so-called 'Asian values' says that priority should be given to social and economic modernisation and development. Another, more specific to China and explored by Lynch (2004) is the claim that the Chinese view democratisation as a challenge to the country's very identity and place in the world. While not rejected for its own sake democratic change is opposed because it threatens to sacrifice an imagined national essence to western-centred narratives and global culture.

Although the idea of democracy first arose in and for the nation state, international democracy promotion in its less consensual manifestations at least seems to imply that choices over political rule should no longer be left solely to national self-determination. Quite obviously, the idea of sovereignty, to which the established democracies still have great attachment in regard to the governance of their own affairs, poses problems for democracy promotion not least where authoritarian rulers reject the democratisation agenda. Whereas sovereignty issues tend to obstruct the supply of international public goods more generally, with powerful states refusing to offer sufficient support (as with development aid in the past) or being reluctant to submit themselves to a universally binding regulatory regime (as in the US's continuing refusal to agree binding cuts in carbon emissions), in democratisation and democracy promotion the impediment appears to be more in countries on the other side, where popular demand for democracy is not allowed effective expression or the authorities deny access to democracy support. In the meantime, however, credulity is 
not overtaxed by arguing that non-democracies free ride on the peace that exists between democracies while not contributing to democracy promotion or, even, paying the democratic 'price' at home. They can gain from the measure of international stability and the advantages bestowed on international trade, commerce and investment that may be attributed to the zones of democratic peace. Such states as China and Russia can be considered as beneficiaries in many ways; perhaps their peoples even share in the aspect of the global good of peace that Mendez (1999: 389) calls 'enjoyment from afar'. At the same time they are very unlikely to fall victim to the reality that democracies sometimes make war on non-democracies. In any case most democracies do not have a reputation for being belligerent, and most nondemocracies can feel secure.

However, while it is not possible to quantify accurately the true size of the demand for democracy and whether a declining market for democracy now exists, even an unfulfilled demand is of course not the same thing as a demand for the attentions of international democracy promotion. To find out more on this it would be instructive to differentiate between the views towards the different approaches, methods or instruments that comprise democracy promotion. Similar to the demand for democracy, which is best understood as not one single market but several markets depending on how democracy is understood, the local circumstances and views about the most prudent pace of change, so it is useful to think of there being discrete markets for democracy promotion, for at least five reasons.

First, the supporters and opponents of reform inside and outside government can be expected to have different views, mirroring their differences on their county’s 
present political condition and on ideas of democracy. Second, the elite's views may not represent popular feeling; and different socio-political groups in the populace will judge the desirability of democracy support in their own way, in accordance with what they believe would be the consequences for them. Third, a reasonable assumption is that attitudes towards democracy assistance are probably much more sympathetic than attitudes towards (threatened) military intervention, except perhaps in the special case of conflict-ridden societies where international humanitarian intervention, peace-making and peace-building are accepted as necessary conditions for building democracy. A government's compliance with democratic political conditionalities when these have been attached to desirable offers of aid, trade or some other concession from abroad cannot be assumed to betoken support for this approach to promoting democracy, although reformers might actually welcome the conditionalities, and some reluctant reformers could value the excuse it provides to concede domestic pressures for change, pragmatically and with honour. Some will think the circumstances can be manipulated to their own personal or partisan political advantage.

Fourth, even within just democracy assistance much anecdotal evidence suggests that views are much less positive in regard to some avenues, for instance support to political parties, than to others, civil society organisations for example. And inside single sectors preferences exist too. For instance in regard to legislative strengthening there seems to be a considerable appetite for infrastructural support, more computers for example, but less support for politically intrusive forms of engagement by outsiders that might comprise more effective strategies. Finally, views may vary according to who is identified as the funding source and the actual provider 
- foreign actors versus local agents (Carothers 2006b warns that many people, both political elites and ordinary citizens, now have a negative view of American democracy support organisations). Common to all these nuances is that more investigation is needed into the actual demand for assistance, in particular the attitudes of ordinary people - many of whom may simply be ignorant about democracy promotion, its limits and possibilities - and not just the individuals, groups and organisations who are partners in assistance programmes and whose role as stakeholders might be expected to colour their view. Without such research there can be no automatic presumption that a demand for democratic change let alone favourable views on an idea of democracy translate into an equivalent demand for democracy support.

Furthermore, when seeking to assess more precisely the demand for democracy assistance there is a sense in which the supply side actors might have to be brought into the equation too, for reasons explained below.

\section{Supply-side}

If public goods tend to be underprovided is this really true of democracy support also? The provision of democracy support is a function of the number of democracies and the commitment of their leaders, among other things. Irrespective of how far democracy promotion can be credited for the increasing number of democracies in the world, one consequence has been to add to the number of actors engaged in offering democracy support. Poland and the Czech Republic are examples of countries that have graduated from the democracy promotion demand side to the supply side. And like India’s contribution as a major founding sponsor of the UN Democracy Fund, 
such recruits bring additional legitimacy if not greater credibility as well to the international promotion of democracy. Legitimacy is something that the global public goods literature maintains may be critical to the success of endeavours intended to address chronic underprovision.

In the same way that development aid evolved from being a 'temporary expedient of cold war diplomacy’ to become much more durable (Lancaster 2007: 5) and adapted its purposes to survive, so democracy support - which escalated in response to the end-of-the-cold war diplomacy - has within a decade or so become institutionalised, that is to say acquired the organisational trappings of permanence. As the policy drivers behind this development have moved to embrace such ideas as democratisation being good for development and reducing domestic conflict, the democratic peace thesis, and democracy as an antidote to international terrorism, signs of being adaptable like this resemble the development aid industry's own past record of showing every intention of being here to stay.

Probably few people have ever doubted that some least developed countries do need some help, although the kind of help that would be most beneficial is more controversial. However a long-standing view claims that a major constituency for humanitarian and development aid is located in precisely those countries that provide it, the donors. This perspective dwells on such aid policy purpsoes as the desire to secure good relations with the governments of the developing countries, for various commercial, economic and political reasons. Moreover the donor country publics have been portrayed as buying a satisfied conscience through acts of charity and supporting official development assistance, which alleviates their sense of guilt. In 
this reasoning, aid supply and demand are to be found in the same place. Mosley (1985) for example portrayed development aid as an 'international public good' where the taxpayers who finance it are the consumers on the demand side. Sogge and Zadek (1996: 70) go even further when they say the 'market demand' for private aid stems from the 'funding authorities'; the voluntary aid agencies act as 'marketmakers', eliciting the 'market' or 'effective demand' that comprises the spending preferences of the donors. In fact there has always been a critical strand to the development discourse, rooted in both socialist and 'free market' perspectives that says poor countries would be better off without much aid. The extent to which this resonates for democracy assistance is debateable. But many comments heard from its recipients do echo the somewhat less critical claim often levelled against development aid, that the offers of assistance and their terms and conditions shape - construct - the demands that the would-be beneficiaries express.

Nevertheless, in the absence of accurate information about the real demand for democracy promotion more generally and democracy assistance in particular it is impossible to estimate an optimum level of supply. When trying to gauge the adequacy it is important not to repeat the mistakes made in the widespread reports of development aid 'fatigue' in the 1989s, when claims about (trends in) aid volumes were conflated with judgments about how (in)adequate these were to address the (growing) problems they were supposed to meet, which were then confused with the reasons that speculation said lay behind the fatigue (see Burnell 1997: 189-92). Moreover on the supply side it is important to distinguish between the professional interest of institutions that have a stake in supporting development or democratisation, or both, and the commitment shown by the political leaders. Although as the 
International Task Force (2006: 77) noted in regard to global public goods, mobilising the concentrated energy of national leaders is a major challenge, very little analytical attention has been given to how any such commitment should be measured. While barometers to measure popular support for democracy in non-democracies are now routine fixtures, there is no democracy support index that measures the international political resolve to extend support.

On measuring commitment to help spread democracy the sums voted for democracy assistance are probably more revealing than formal statements of support, even though by comparison to development aid, the monetary value may be less important than are democratic reputation, political sensitivity and skill in the way support for democratic objectives is extended. In line with the global public goods literature constructive participation in international cooperation, and support for multilateral initiatives, could be another proxy indicator. But should a willingness to employ the less consensual approaches to promoting democracy, like political conditionalities and diplomatic pressure for instance, necessarily be read as denoting stronger support? Does the promotion of democracy not just for the sake of democracy or democratic peace but to serve the other interests of the democracies itself betoken a sign of weakness? Shallow commitment, in contrast, is perhaps easier to pin down, namely where foreign policy sacrifices democratic goals to the expedient pursuit of vital strategic interests, examples of which in a European context are provided by Youngs (2006) and Jünemann and Knodt (2007). Youngs’ (2006) portrayal of the relatively lukewarm commitment of certain European governments like Spain’s and France's may qualify them as free-riders on more active EU member states. But the fact that even the democratic peace must compete for attention with 
other global and international as well as national public goods cannot be ignored, notwithstanding the symbiotic relationship that many of the different public goods may have to one another.

Even when engaging in the more straightforward task of calculating the amount of democracy assistance, not only is this a very inexact science for reasons already noted but there are some indications - most notably in the US - that the sums could soon begin to level off, or even fall. Recent levels of appropriation including for the NED have been heavily biased by special earmarking (most notably for political projects in Iraq) which risks diluting the overall quality and effectiveness. These will not continue indefinitely. The NED's (2007) own view that democracy assistance is 'now under attack from many quarters’ refers to hostility at home as well as abroad. The backlash is in Washington as well as much further afield, something that itself could be attributed democratic credentials in as much as it reflects public attitudes, gleaned by US German Marshall Fund (2006) surveys that show falling levels of support in the US for the idea that the US should try to help establish democracy in other countries (the support of 71 per cent in Europe compared favourably with the 45 per cent recorded in the US, which concealed even weaker support among Democrats). Even in Europe the shadow of regime change and a disposition to associate democracy support with hegemonic pretensions of the US does seem to harm enthusiasm for promoting democracy among Europe’s left-wing politicians (Mathieson and Youngs 2006) - precisely the spectrum that might otherwise have been expected to offer firm support, given its traditional alignment with human rights causes and internationalist positions. This weakness is reinforced by Europe's inability to decide how to position its democracy support in relation to US efforts now 
that EU enlargement is almost complete, in parts of the world that will never be candidates for accession. Should European and other actors cooperate more closely with the Americans? And in what ways should Europe try to be very distinctive in its democracy assistance ambitions, activities and designs? Failure to date to completely resolve these questions trouble some Europeans and probably reduce the impact of their commitment to supporting democracy.

Furthermore, the theory that democracy benefits development, which in the 1990s in the foreign and development policy circles of many developed donor democracies had provided some intellectual underpinning for democracy promotion, probably offers less support now. The priority accorded to state capacity-building in some countries and, almost everywhere much-needed improvements in governance and the rule of law are currently accorded great importance. Faith in the stronger merits of indirect strategies for achieving political change in developing countries through efforts aimed in the first instance at creating what may be necessary economic and social conditions for stable democracy, through development aid, commands considerable support in the aid bureaucracies and the development discourse. Meanwhile, even a note of intellectual scepticism towards the idea of a democratic peace has crept in, namely the very controversial argument that notwithstanding peace among democracies the process of becoming a democracy (that is, democratisation) increases the risk of war (see Mansfield and Snyder 2005).

These are not the only problems that stand in the way of characterising not so much the present levels and trends in democracy assistance but more significantly, its actual performance - the results it achieves. An issue that has started to command 
much attention only recently is the realisation that we do not really know how much of democracy promotion works, what works best, and how well. More particularly there is the recognition that we do not yet have methodological tools adequate for making reliable measurements even of the impact and effectiveness of democracy assistance, let alone all the other ways of trying to promote democracy and for comparing the performance of the different methods, instruments or approaches (see Burnell 2008). There is disagreement even about what can be measured by quantitative techniques and their worth relative to more qualitative-based assessments (see Burnell 2007). The grounds for wanting to establish whether democracy assistance works and which kinds work best hardly need much elaboration, although it is USAID that has gone farthest in trying to quantify the benefits and claim positive results (see Sarles 2007) - which is a reflection of the budget line's political vulnerability in the US. One ground, based on Mosley’s (1985) study of economic development aid is that perceptions of its quality may exert an influence upon the supply, through the consequences for the amount of political support that is offered. The impatience of law-makers to see convincing evidence that democracy assistance represents good value for money, however, can distort the assessment process and may engender misleading results. Where democratisation itself is a slow process and moves in a jagged or uneven way, international support and its evaluation should both take the long term view. In the US meanwhile concern has been voiced that claims for the successes of US democracy support can be counterproductive, by stiffening the resistance among democracy’s opponents and making it more difficult for democracy assistance partners to cooperate openly with external help. Contrary to what has been said about development aid, then, the real value of democracy support may sometimes move in inverse relationship to public perceptions of its worth. 
In summing up the market-place, just as the democracy promoters claim to tailor their activities to the demand for democracy, so the demand for democracy and the constituency for democracy support are not wholly independent of how democracy promotion and the underlying motives are perceived. Changes in demand and supply for democracy promotion are in some degree mutually constitutive. For example the part played by democracy support in the so-called 'colour revolutions', Ukraine’s especially, is often credited with stiffening Putin’s opposition to democracy assistance activities in Russia. As with the challenge the EU faces of how to maintain its record by repeating the pro-democracy effects of enlargement in much less promising situations, success can appear to bring its own problems. Some evidence around the world suggests that market sentiment towards democracy is weakening; and political resistance to reform has increased. All this offers the democracy promoters grounds for being more pessimistic about their efforts compared to fifteen years ago, when the democratisation tide bore up confidence. But even though extensive hard evidence about democracy promotion's performance is starting to be assembled only now, we cannot yet conclude that democracy promotion has moved from being the demandinspired activity seen in the 1990s towards becoming more of a supply-driven phenomenon kept alive by institutionalisation in the industry now. What is clear, however, is the contrast in fortunes with international development cooperation. The foreign aid industry has acquired a new buoyancy, born of a belief that the solutions to development problems are now better understood (helped by recent development success stories such as China, India and Vietnam) and that in the post-cold war period aid's policy objectives have become increasingly sympathetic to the goal of povertyreduction. And of course the budget declines of the 1990s have been reversed. The 
contrast - shown in suspicion that the rise to prominence of national and regional security issues in foreign policy thinking has been detrimental to a consistent commitment to promoting democracy; the growing reservations about prioritising democracy-building ahead of consolidating the state structures, the socio-economic conditions, and the rule of law (often referred to as 'getting the sequencing right') together with the persistent belief that domestic factors are more compelling than international factors as explanations of democratisation; plus concerns over how to measure the impact of democracy assistance let alone its true performance - all could not be more striking. Carothers’ (2006a: 56) pertinent remark that the 'backlash’ against democracy promotion is 'multi-layered' could indeed be extended beyond the opposition by real political interests to encompass a variety of assaults on the intellectual reasons for promoting democracy too.

\section{Conclusion}

Theorising about global public goods is not yet fully developed. And yet already, by starting out from origins in a scholarly literature the idea of public goods has been stretched by its recent application to the examination of global issues of growing international concern. Like public goods per se, the instances of undisputed pure global public good are probably very rare. Nevertheless in some of its aspects recent literature on global public goods speaks to the contemporary state of international democracy promotion. While that state comprises a mixture of both positive and negative aspects as seen from the perspectives of actors centrally involved in trying to promote democracy, there is considerable scope for attaining more knowledge and better understanding of the exact nature of the market-place, including the origins and detailed specification of the demand. On the side of provision, uncertainties about the 
problem of collective action and the feasibility of alternative policies are but two notable features that the discourse says are also common to all global public goods (Kaul, Grunberg and Stern 1999b: xxvi). Peace, democracy, and the democratic peace, separately and in terms of the causal relationships they may have to one another are all undersupplied relative to the general assumptions of their desirability. There is not simply market failure but, as with many global public goods, political failure too: the prevalence of stalled democratisations and democratic reversals tells us that international democracy promotion has not been adequate or wholly effective. That international democracy promotion cannot be described as a global public good in the purest sense seems clear, notwithstanding the potential it might have for helping to bring about such goods as a democratic peace. Nevertheless, although the idea of intermediate global public goods is fairly new, arguably in this sense effective democracy assistance could be thought to exhibit some of the properties of at minimum of an international public good.

Just as the publicness and privateness of many 'public goods' may not be fixed for ever, so the correct balance between private and public and between state-led versus intergovernmental, multilateral and supra-national provision is not rigidly prescribed by global public goods theory either. Indeed the literature assumes that for many global public goods, national level provision will often come first. This has certainly been true of democracy promotion. However, recent writing on global public goods agrees that more meaningful international cooperation and, probably, greater provision by international public institutions (with the United Nations in the van) could be essential, even though such responses cannot be expected to resolve for all time arguments over where the correct balance between principles of sovereignty and 
international intervention in a country's politics should lie. These views may well have relevance to democracy assistance too, even though in the present climate especially there are reasons why democracy promotion actors outside the US might not want to (be seen to) collaborate too closely with the US government in these matters. So far a measure of political failure in organising democracy support has compounded the market failure for democracy assistance, although to call it a spoiled market in the light of the shadow cast by regime change and the confused association with US hegemony would be going too far. But however damaging these current weaknesses on the supply side are, the normal preoccupation of public goods theory with the defining problem that is underprovision should not obscure the fact that in democracy promotion problems exist on the demand side too. That refers not just to the restrictions on access both to democracy and to receiving democracy support that obtain in many countries. For as the supply of democracy promotion has become more institutionalised it means also the difficulty of establishing the true demand for different kinds of democracy support, and separating those out from the undoubtedly well-intentioned but not wholly disinterested demand-raising promptings of supply side actors too.

The geo-economic and geopolitical context for efforts intended to spread democracy are much less favourable now than they were at the time of the fall of the Berlin wall. Predictions about future support for promoting democracy remain hostage to near term electoral politics inside the established democracies, most notably the US. The shape of future developments inside such international organisations as the UN and EU looks very uncertain too. Unlike certain public goods where a reluctance to commit substantial public funds is a major reason for there 
being too little supply, the commitment to democracy promotion is beholden to a more complex and shifting matrix of forces that influence foreign policy and international relations. Today the non-democracies include weak or fragile states and some very poor countries. They do not offer easy places in which to establish democracy. The challenge that democracy promotion now faces looks greater than before even as attitudes towards it have become less confident: these two trends are of course not unrelated. It is possible that withholding democracy support on the grounds that the prospects for democratic advance look bleak could have a self-fulfilling quality; and something similar may be true for many instances of public goods. Remaining largely silent towards predictions (other than presuming that global problems will intensify) while being in making recommendations is a feature of some recent global public goods literature that is worthy of emulation. Nevertheless, further developments in the application of global public goods theory for the purpose of identifying, analysing and addressing major problems may be worth tracking, for the insights they might give on the international promotion of democracy to the end of securing greater international peace.

\section{References}

Ambrosio, Thomas (2007) 'Insulating Russia from a Colour Revolution: How the Kremlin Resists Regional Democratic Trends', Democratization 14/2: 232-52.

Brinks, Daniel and Coppedge, Michael (2006), 'Diffusion Is No Illusion', Comparative Political Studies, 39/4: 463-89.

Burnell, Peter (1997), Foreign Aid in a Changing World (Buckingham and Philadelphia: Open University Press). 
Burnell, Peter (2005), 'Political Strategies of External Support for Democratization’, Foreign Policy Analysis, 1:3, 361-84.

Burnell, Peter (ed.)(2007), Evaluating Democracy Support. Methods and Experiences (Stockholm: International Institute for Democracy and Electoral Assistance and Swedish International Development Cooperation Agency).

Burnell, Peter (2008), ‘From Evaluating Democracy Assistance to Appraising Democracy Promotion', Political Studies, forthcoming (available OnLineEarly).

Carothers, Thomas (2006a) ‘The Backlash against Democracy Promotion’, Foreign Affairs, 85/2 (April): 55-68.

Carothers, Thomas (2006b), 'Responding to the Democracy Promotion Backlash’, Testimony to the US Senate Foreign Relations Committee Hearing, 8 June 2006, at http://www.carnegieendowment.org (accessed 27 June 2006).

Dalacoura, Katerina (2006), 'Islamist Terorism and the Middle East Democratic Deficit’, Democratization, 13/3, 508-25.,

Department for International Development (2007) Governance, Development and Democratic Politics (London: Deportment for International Development). Diamond, Larry (2007), telephone contribution to Kojo Nnamdi Show, 'US Foreign Policy and Democracy Promotion', WAMU 88.5 FM American University Radio, 20 June 2007.

Gershman, Carl and Allen, Michael (2006) 'The Assault on Democracy Assistance’, Journal of Democracy, 17/2: 36-51.

Hamburg, David and Jane Holl (1999), 'Preventing Deadly Conflict', in Kaul, , Grunberg and Stern (eds)(1999a), pp. 366-80. 
Hodgson, Geoffrey (2001), 'Markets as Institutions', in R. B. Jones (ed.), Routledge Encyclopaedia of International Political Economy, volume 2 (London and New York: Routledge), 980-84.

International Task Force on Global Public Goods (2006) Meeting Global Challenges: International Cooperation in the National Interest http://www.gptaskforce.org/bazment.aspx (accessed 23 July 2007). Jünemann, Annette and Michèle Knodt (2007), ‘Explaining EU Instruments and Strategies of EU Democracy Promotion. Concluding Remarks’, in Annette Jünemann and Michèle Knodt, European External Democracy Promotion (Baden-Baden: Nomos Verlagsgesellschaft) 353-68.

Kaul, Inge, Isabelle Grunberg and Marc A. Stern (eds)(1999a) Global Public Goods. International Cooperation in the Twenty First Century (New York and Oxford: Oxford University Press).

Kaul, Inge, Isabelle Grunberg and Marc A. Stern (1999b), Introduction’, in Kaul, Grunberg and Stern (1999a), xix-xxxvii..

Kaul, Inge, Isabelle Grunberg and Isabelle and Marc A. Stern (1999c), 'Defining Global Public Goods’, in Kaul, Grunberg and Stern (1999a), 2-18.

Kaul, Inge, Pedro Conceição, Katell Le Goulven and Ronald U. Mendoza (eds) (2003a) Providing Global Public Goods (Oxford and New York: Oxford University Press).

Kaul, Inge, Pedro Conceição, Katell Le Goulven and Ronald U. Mendoza (2003b), 'How to Improve the Provision of Global Public Goods', in Kaul, Conceição, Le Goulven and Mendoza (eds) (2003a), 21-58. 
Kaul, Inge and Ronald U. Mendoza (2003), ‘Advancing the Concept of Public Goods’, in Kaul, Conceição, Katell Le Goulven and Mendoza (eds)(2003a): 78-111.

Lancaster, Carol (2007) Foreign Aid: Diplomacy, Development, Domestic Politics (Chicago: University of Chicago Press).

Lynch, Daniel (2004) 'International “Decentering” and Democratization: the Case of Thailand', International Studies Quarterly, 48/2: 339-62.

Mansfield, Edward and Jack Snyder (2005), Electing to Fight. Why Emerging Democracies Go to War (Cambridge, MA: The MIT Press).

Mathieson, David and Youngs, Richard (2006) Democracy Promotion and the European Left: Ambivalence Confused?, Working Paper 29 (Madrid: Fundación para las Relaciones Internacionales Y El Diálogo Exterior). McFaul, Michael (2004-5), 'Democracy Promotion as a World Value’, The Washington Quarterly, 28/1: 147-63.

Mendez, Ruben (1999) 'Peace as a Global Public Good’, in Kaul, Grunberg. and Stern (1999a), 382-416.

Mosley, Paul (1985) 'The Political Economy of Foreign Aid: A Model of the Market for a Public Good', Economic Development and Cultural Change, 33/ 2: 37393

National Endowment for Democracy (2007), Strategy Document January 2007, http://www.ned.org (accessed 23 July 2007).

Policy Unit of the European Council General Secretariat (2006), The EU Approach to Democracy Promotion in External Relations: Food For Thought, www.democracyassistance.eu (accessed 23 July 2007). 
Puddington, Arch. (2007) ‘The 2006 Freedom House Survey. The Pushback Against Democracy', Journal of Democracy, 18/2: 125-37.

Sarles, Margaret (2007), ‘Evaluating the Impact and Effectiveness of USAID’s Democracy and Governance Programes’, in Burnell (ed.)(2007), 47-68.

Sen, Amartya. (1999) 'Democracy as a Universal Value’, Journal of Democracy, 10/3: 3-17.

Sogge, David and Zadek, Simon (1996) '”Laws” of the market?’, in D. Sogge (ed.), Compassion and Calculation (London: Pluto, 1996), 68-96.

The Democracy Barometers (Part I)(2007), Journal of Democracy, 18.3: 65-125.

US German Marshall Fund, Transatlantic Trends 2006, http://www.transatlantictrends.org (accessed 23 July 2007).

Youngs, Richard(ed.) (2006), Survey of European Democracy Promotion Policies 2000-2006 (Madrid: Fundación para las Relaciones Internacionales y el Diálogo Exterior). 